\title{
Analysis of ABh ad Nś 4.261cd-269ab
}

1. The opponent's doubt (pürvapakșa [PP]= Nś 261cd-263ab)

1.1. Introduction to the $P P$

1.2. Doubt: Is dance different from theatre or not? If different, does it have a purpose?

1.3. First thesis/abhedapakșa: Dance is no different from theatre

1.3.1. Argument of the abhedapakșin [AP]: Dance and theatre have the same characteristics; they contain bodily movements and songs

1.3.2. Dance, just like theatre, contains acting that is applied to a text rendered through singing, whose content has to be brought into being

1.3.3. Minor differences in characteristics do not constitute a difference in nature, even among the ten dramatic genres. Example: having a single performer and using ākáśabhāṣita are characteristics of the monologue play Bhāṇa

1.3.4. Rāhula (supporting 1.3.3): Dance uses the theatrical conven-

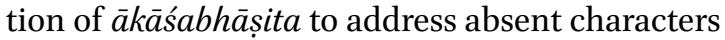

1.3.5. Bharata (supporting 1.3.3): The lāsya dance, like the Bhāna, is enacted by a single performer

1.3.6. Vārttika (supporting 1.3.1): Theatre and dance both express textual content through bodily movements; thus they are not different

1.4. Objection of the bhedapakșin [BP]: Dance is different from theatre, since it produces no evident cognition of the contents enacted

1.4.1. AP: No, since cognitions of the imitated characters in specific situations arise also in dance

1.5. Intermediate proposal of the в $\mathrm{P}$ : In dance, acting is performed to a text that is sung (as per 1.3.2)

1.5.1. Objection of the AP (reinforcing 1.3.3): Minor differences in characteristics do not constitute a difference in nature; in theatre too we see a dramatic text delivered through singing, for instance in the nātyāyita

1.6. Imaginary objection of the BP: The Dombikā etc. are not theatre, since they are not included among the ten dramatic genres

1.6.1. Answer of the AP: This is inconclusive, since there are other dramatic forms not listed by Bharata, and since Kohala has included dramatic genres along with dance genres 
1.6.2. AP: All the different registers of acting are seen in dance as well, though in different degrees, as in the lāsyāingas

1.7. Imaginary objection of the BP: The various segments in a Dombikā etc. are not reciprocally connected, while in theatre they are all connected to the main topic

1.7.1. Answer of the AP: Even in dance there is a main themeeither the praise of the deities or the amorous rasa-as argued by Bharata, and as is demonstrated in the Dombikā genre, which declares its theme at the outset

1.8. Conclusion of the first view, or abhedapakșa: Dance is no different from theatre, since it has its same characteristics

1.9. Recapitulation of the PP: Since acting has been devised for grasping the meanings of a poetic composition as if they were directly present, why has dance been designated with a different word?

1.10. Abhyupagama: Examination of the second view, or bhedapakșa: Dance is different from theatre

1.10.1. Objection of the AP: If dance is different from theatre, what nature and characteristics does it have?

1.10.2. AP: If dance were considered to be worldly, it would be just a shadow of theatre; if otherworldly, it would be a subspecies of theatre

2. The вр: Dance as an independent genre

2.1. BP: If dance were imagined to be a subspecies of theatre (as per 1.10.2), it would still have a different purpose; it would be characterized by the bhāvas

2.2. AP: No, because we see instruction in the aims of mankind also in the rāgakāryas and other danced genres

2.3. AP: It is not possible to establish a difference between theatre and dance on the basis of purpose

2.4. First interpretation of the PP (against 2.1): Since the danced genres have been devised for attaining the ends of men, why should dance not be theatre? Since their characteristics and purpose are the same, they cannot but have the same nature

2.4.1. Vārttika supporting AP (2.2)

2.5. Conclusion of the AP: Dance is no different from theatre since their nature and purpose are no different

3. Dance within the play

3.1. Intermediate proposal of the вр: The danced genres are dramatic because they use enactment, but abstract dance that is devoid of it is not 
3.2. Objection of the AP: What would be the purpose of such dance?

3.3. Answer of the BP: It is used in theatre as an element of bodily acting

3.4. Second interpretation of the PP (against 3.3): In theatre, the means of enactment are useful for attaining the meanings as directly manifested, but dance that is devoid of enactment has no purpose of its own

3.4.1. Imaginary objection of the BP: Dance is employed for allure, like songs and instrumental music

3.4.2. Answer of the AP: Songs do communicate implicit meaning in theatre, and music coordinates the instrumentation and the enactment; but what is the purpose of dance?

3.5. Answer of the BP: Dance is used in theatre for combat and other movement on stage

3.6. The AP retorts: In that case, what is the nature of dance? If worldly, it would be a kind of bodily acting; if otherworldly, it would be counted as nattyadharmi and abides by theatrical convention

4. Dance in the pürvarainga

4.1. Intermediate proposal of the вр: Dance is used for multifariousness in the pürvarainga

4.2. Question of the AP: Even then, is it performed simultaneously with songs or in a certain relation of principal and subordinate?

4.2.1. The first case would lead to impropriety, but as dance is connected with music, it must be a form of bodily acting

4.2.2. The narrative about the introduction of dance in the pürvaranga supports 4.2 .1

4.3. Third interpretation of the PP (against 4.1): If enactment is devised for conveying the meanings of the songs before the spectators, why should one call it 'dance'? If dance is used to enact the content of a song, what different nature, other than bodily acting, could it have?

4.4. Intermediate proposal of the BP: Dance is not used as an enactment in connection with songs

4.5. Question of the AP: How then is dance used in connection with music?

4.6. Interpretation of the second part of the PP (against 4.4): Dance is not connected with songs, i.e. it is not counted as one of its constituent elements, since it belongs to a different class

4.7. Imaginary objection to 4.6 by the BP: Dance is used with songs like instrumental music

4.8. Answer to 4.7 in the PP: Dance does not bring any object into being, i.e. it does not forward the goals aimed at by music 
4.8.1. Elaboration of 4.8 by the AP: All the different musical instruments contribute to either the melodic, rhythmic, or lyrical part of music. Dance falls under the lyrical part; therefore it is a form of acting (4.2.1) and thus no different from theatre (4.3)

4.9. Intermediate proposal of the $\mathrm{BP}$ : Dance, consisting in recakas and angahāras, does not enact the meanings, but brings about a good result, just like ritual formulas and visualizations

4.9.1. Bharata supports the connection of the angahäras with the various components forming the songs of the pürvarainga

4.10. The AP: Given the BP's premises, such a connection amounts to nothing

5. Summary of the PP as threefold: Dance cannot be established as different from theatre if we intend it as:

5.1. An independent genre

5.2. Part of the play

5.3. Part of the pürvariga in connection with songs

6. Uttarapakșa: Refutation of the pürvapakșa

6.1. Avataranikā of the three verses of Bharata refuting the PP (Nś 4.263cd-266ab)

6.2. The uttarapakșin (UP) or вP, correcting 1.3.1: To say that forms of staged dance like rāgakāryas are no different from theatre since they contain bodily movements and songs is inconclusive, since the logical reason extends to mundane dance

6.3. Answer of the AP, recalling what said in 1.4.1 and recapitulating the sense of abhinaya in the PP 1.9: Unlike in staged dance and theatre, in mundane dance the words, whether a) recited or b) sung, are c) neither enacted $d$ ) nor are they brought to direct perception

6.4. UP: Dance does not conform to any object to be brought to direct perception (against 1.9)

6.4.1. The UP, refuting 6.3: It is not established that only in theatre and staged dance are meanings enacted, because a) in the world, gestures accompany words, and b) singers use some form of enactment

6.4.2. Further fallacy of $6.3 \mathrm{c}$ ): If forms lacking abhinaya fall outside the scope of theatre, then this applies to forms of staged dance as well. An example is the Dombikā, echoing 1.5: the meaning of the song is brought out through singing, and bodily movement just adapts to its delicate form, without enacting it 
6.4.3. Refutation of $6.3 \mathrm{~d}$ ): In the Dombikā, there is no direct perception of the content of the song, since we cannot attribute the dialogues to a character uttering them

6.4.4. Description of the narrative phase of a Dombikā, which aims at charming the king through song, dance, and music

6.4.5. Description of the dance phase of a Dombikā, where the song is taken up by the vocalist, and the dancer does not enact its content, but just follows the rhythmic and melodic patterns

6.4.6. Instruction is not the aim of the Dombikā (against 2.2), since the dancer-performer does not show the dombika as similar to a directly perceived character

6.4.7. The gestures of the dancer are mainly for display-they are not a form of bodily acting; thus, dance only metaphorically shares the features of theatre

6.5. To say that dance is like the prologue, life, or reflection of theatre is metaphorical speech, since no restriction on bodily movement, language, or costume with respect to contents or characters applies to the lāsyāingas of the pürvaranga

6.5.1. The lāsyāngas do not use ākāśabhāṣita like the Bhāna, since they have no dramatic dialogue, but songs (against 1.3.3 and 1.6.2)

6.5.2. There is no anukärya in dance, since the dancer does not wear a costume appropriate to the character (against 1.4.1)

6.5.3. The nature of nātyāyita cannot be attributed to lāsya dance (against 1.5.1), since the nātyāyita is a reaction to the emotional core of a song, not just its gestural rendering

6.5.4. Similarly, the nature of nātyāyita cannot apply to nrttakārya, since the psychophysical states triggered by the song do not affect the acting in the latter

6.6. Dance does not conform to any object to be taught (against 2.1)

6.6.1. The UP: Dance has a different aim than theatre; though pleasure and instruction may be obtained secondarily, its primary aim it to satisfy the deities, which is an invisible result

6.6.2. Even the Dombikā as a staged form aims at satisfying the deities, though the dombika as its embedded character aims at delighting the king and earning material gain, which is a visible result

6.6.3. Both the dancer and her patron aim at satisfying the deities through dance, as supported by an anonymous quotation 
6.6.4. Objection of the AP (recalling 2.2): Pleasure and instruction are experienced in dance just as in theatre, by adding a pleasurable element to the pedagogical content of the text

6.6.5. Answer of the UP: It should be the same for songs, too. The difference is that in theatre, instruction in the aims of man is principal, just like in Purānic storytelling. Thus the result of dance is different from that of theatre

6.7. The UP announces a further difference in the characteristics of dance and theatre

6.8. The UP: The logical reason behind the commonality of characteristics and purpose in theatre and dance is not established

6.8.1. Restatement of Bharata's UP (according to 6.4): Dance does not conform to any object to be directly manifested

6.8.2. Restatement of Bharata's UP (according to 6.6): No object in dance depends on instruction in the means to attain the goals of men

6.8.3. Conclusion of the UP: Therefore, dance is different from theatre, which invalidates the threefold PP (as per 5.1-3)

6.9. Objection of the PP, recalling 3.2: If it is different from theatre, what would be the use of dance within it?

6.9.1. Counter-objection of the UP: What about songs?

6.9.2. Answer of the PP, recalling 3.4.3: As previously stated, songs provide additional content

6.9.3. The UP, showing the faults in the PP's reasoning: Then let songs be simply recited without the notes and embellishments

6.9.4. Readjustment of the PP, recalling 3.4.1: We agreed that what is pleasurable helps in grasping the meanings

6.9.5. The UP: This is indeed how dance is used in theatre, which moreover guarantees its cognition as a fire-wheel

6.10. The UP, stating the positive role of dance as meant to create beauty, which helps the aesthetic experience

6.11. Imaginary objection: charm is not specific to dance, but to other pleasurable actions as well, like eating

6.11.1. In this connection, Bharata utters the next verses (NŚ $4.264 \mathrm{~cd}-266 \mathrm{ab}$ ), where the pleasurable nature of dance is connected with its auspicious character

6.11.2. The link between dance and beauty has already been stated in connection with the kaisiki vrttti 
7. Avataranikā to Nś 4.266cd-267ab: What is the nature to which dance conforms?

7.1. Dance was introduced in the pürvarainga because the dry syllables were rejected by the gods and put into practice by the Bhūtas

7.2. UP: Abstract dance is performed in the musical segments containing dry syllables, which are used at the beginning of songs

7.2.1. Therefore, it is not true that dance can only be included among the elements of a song provided it is a kind of bodily acting [refutation of 4.8.1]. Kriya ars are an example to the contrary

7.2.2. To say that dance is used to enact the meanings of a song is metaphorical

7.2.3. Abhinaya is also used in a secondary sense in storytelling (as stated in 6.4.1 against 6.3)

7.2.4. A deviant interpretation of the word pratikșepa in the verse

7.2.5. A second acceptable interpretation of the word pratikșepa in the verse

7.3. Conclusion: Dance is used purposefully within theatre and in the pürvaranga in connection with songs

8. Avataranikā to Nś $267 \mathrm{~cd}-268 \mathrm{ab}$ : Bharata illustrates the scope of narrative dance through a story of the past

8.1. Siva asks Tandu to connect dance with the text of the songs

8.2. Story of the past (justifying 8.1): While Śiva was dancing, Nārada sang a story and enacted it; Śiva asked Taṇu to connect the tāndava with the acting

8.3. Doubt introducing Nś 4.268cd-269ab: What is the semantic scope of the word tạndava?

8.4. Answer: Tândava refers to the totality of dance, and lāsya is a particular case of it

8.4.1. Tândavavidhi as a vehement dance performed to a poem in praise of the deities in which dharmavira is the main rasa

8.4.2. Sukumāraprayoga as a delicate dance performed to a poem in which śrngāra is the main rasa

8.4.3. Rasa is found in theatre, and poetry is a part of it, thus it contains rasa. When dance is connected with the rasa in a poem, it is metaphorically called 'theatre'

8.5. Mixed uses of dance depend on the topic of the poetic text

8.5.1. Exemplification of mild and vehement dance in the existing genres 
8.5.2. Definitions of the genres of narrative dance given by the ancients

8.5.3. Despite their having several topics, these genres find unity in the praise of the deities or the amorous rasa (refuting the objection of unconnectedness adduced by the BP in 1.7)

8.5.4. Definition of the rāgakārya

8.5.5. In rāgakārya, the melodic pattern and language are independent of the poetic meaning

8.6. Conclusion: Śiva created dance in seven forms, and Tandu connected it with the musical accompaniment, as well as with the poetic text

8.6.1. Two main divisions among the seven forms: abstract dance, and dance connected with songs.

8.6.2. Recapitulation of the narrative told in chapter 4 